\title{
The ABO blood groups of carcinoma of the oesophagus and of benign prostatic hyperplasia
}

\author{
W. H. BEASLEY \\ From the General Hospital, Aberystwyth
}

SYNOPSIS The results of an investigation show that there is no statistically significant excess blood group $\mathrm{A}$ in cases of carcinoma of the oesophagus or in cases of benign prostatic hyperplasia

It has been shown that an association, based on large numbers of cases, exists between the ABO blood groups and gastro-duodenal disease. However, there have been a few reports only of the distribution of the ABO blood groups in oesophageal carcinoma. This paper adds a further 272 cases.

\section{CARCINOMA OF THE OESOPHAGUS}

Squamous carcinoma of the oesophagus only is considered in this report, for it was assumed that an adenocarcinoma in the lower third was gastric in origin. The cases were obtained from hospitals in Monmouthshire, Cardiff, Sully, and Bristol, and Table I shows their distribution. The areas designated Glamorgan I and Glamorgan II were defined in a previous report (Beasley, 1960) and the ABO blood groups of the control populations of Glamorgan and Monmouthshire were provided by the Nuffield Blood Group Centre. The controls for the Bristol cases were taken from the report by Aird, Lee, and Roberts (1960). Statistical analysis of the material according to the method of Woolf (1955) shows that

Received for publication 16 May 1963. there is no significant excess of group $A$ in squamous carcinoma of the oesophagus in these areas.

Two other series have been published, one by Billington (1957) and another by Aird et al. (1960) In Table II there is a combined analysis, but to avoin any possible duplication, the cases at Cardiff ant Bristol used by Aird $e t$ al. have been excluded. Th $\vec{B}$ value for $\chi^{2}$ for the three series is 3.34 which is nois quite a statistically significant result, and the man areas in the series are statistically homogenous. Thus carcinoma of the oesophagus does not appear to possess the same relationship to group $A$ that has been found for carcinoma of the stomach. There $\frac{0}{18}$ one inexplicable peculiarity about the figures and that is the high incidence of groups $A$ and $A B$ in the Bristol series, but in the analysis only groups $\mathrm{O}$ and $\mathrm{A}$ were used.

\section{BENIGN PROSTATIC HYPERPLASIA}

There have been three previous accounts of the distribution of the $\mathrm{ABO}$ blood groups in benigg prostatic hyperplasia (Walther, Raeburn, and Case 1956; Prosser, 1959; Bourke and Griffin, 1962). Thts paper reports a series of $\mathbf{4 4 5}$ cases, histologically diagnosed, from hospitals in Monmouthshire (Tabe

TABLE I

ABO BLOOD GROUPS AND SQUAMOUS CARCINOMA OF THE OESOPHAGUS

Reported Series

Blood Groups

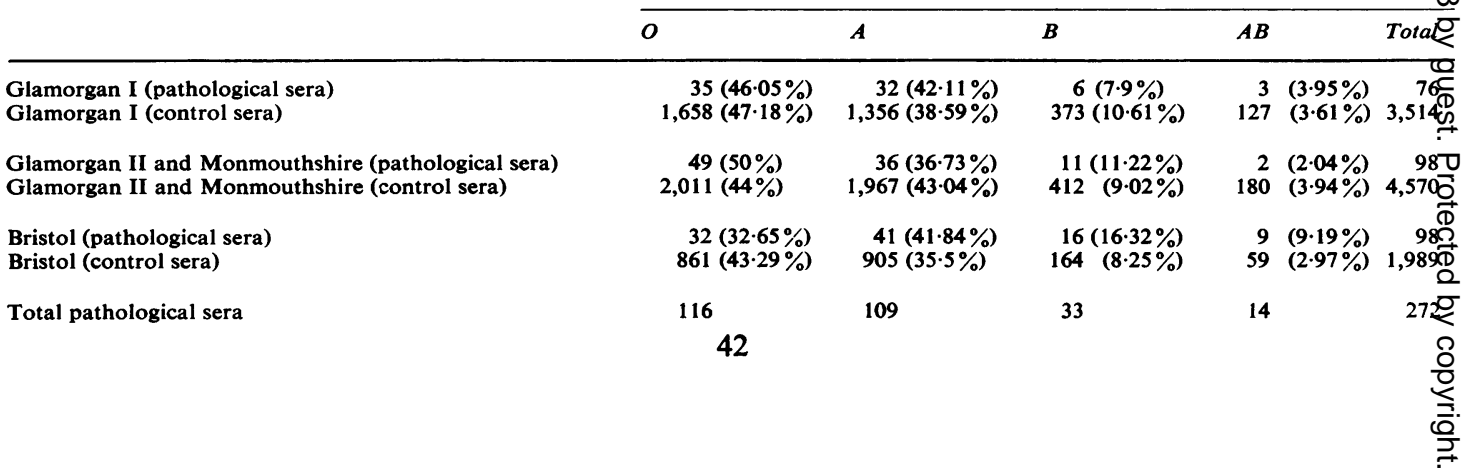


TABLE II

COMPARISON OF INCIDENCE OF BLOOD GROUPS A AND O IN SQUAMOUS CARCINOMA OF OESOPHAGUS

Reported Series

Blood Groups

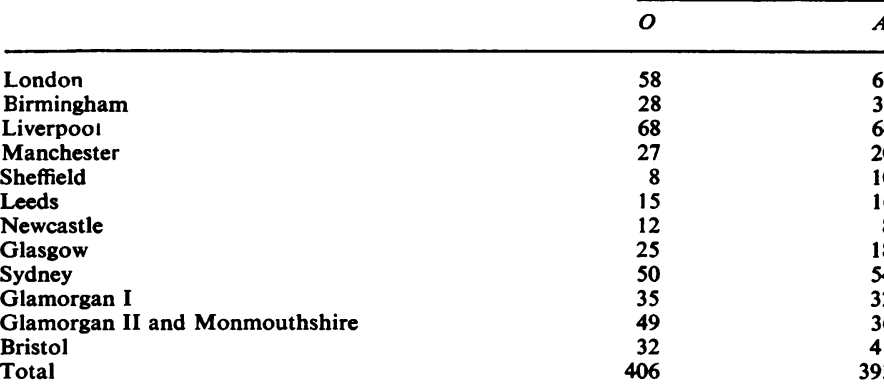

Mean weighted relative incidence Total

$x^{2}$ Differences from unity (D of F) $=1$

Heterogeneity (D of F) $\quad=11$

P Heterogeneity

TABLE III

ABO BLOOD GROUPS IN BENIGN PROSTATIC HYPERPLASIA

Reported Series

Blood Groups

\begin{tabular}{|c|c|c|c|c|c|c|c|}
\hline & & $\boldsymbol{O}$ & $A$ & $\boldsymbol{B}$ & $A B$ & & Total \\
\hline Walther et al. (1956) & $\begin{array}{l}\text { Pathological sera } \\
\text { Control sera }\end{array}$ & $\stackrel{36}{1,070(46.03 \%)}$ & $\begin{array}{c}56 \\
1,023(43.99 \%)\end{array}$ & $\begin{array}{l}4 \\
159(6.84 \%)\end{array}$ & $\begin{array}{r}4 \\
73\end{array}$ & $(3 \cdot 14 \%)$ & $\begin{array}{r}100 \\
2,325\end{array}$ \\
\hline Prosser (1959) & $\begin{array}{l}\text { Pathological sera } \\
\text { Control sera }\end{array}$ & $\begin{array}{c}76(38 \%) \\
3,090(38.63 \%)\end{array}$ & $\begin{array}{c}92(46 \%) \\
3,740(46.75 \%)\end{array}$ & $\begin{array}{c}20(10 \%) \\
834(10 \cdot 42 \%)\end{array}$ & $\begin{array}{r}12 \\
336\end{array}$ & $\begin{array}{l}(6 \%) \\
(4 \cdot 2 \%)\end{array}$ & $\begin{array}{r}200 \\
8,000\end{array}$ \\
\hline Bourke and Griffin (1962) & $\begin{array}{l}\text { Pathological sera } \\
\text { Control sera }\end{array}$ & $\begin{array}{r}117(43 \cdot 2 \%) \\
4,580(45 \cdot 8 \%)\end{array}$ & $\begin{array}{r}113(41 \cdot 6 \%) \\
4,220(42 \cdot 2 \%)\end{array}$ & $\begin{aligned} 26 & (9.6 \%) \\
890 & (8.9 \%)\end{aligned}$ & $\begin{array}{r}15 \\
310\end{array}$ & $\begin{array}{l}(5.5 \%) \\
(3.1 \%)\end{array}$ & $\begin{array}{r}271 \\
10,000\end{array}$ \\
\hline This series & $\begin{array}{l}\text { Pathological sera } \\
\text { Control sera }\end{array}$ & $\begin{array}{l}193(43 \cdot 37 \%) \\
986(43 \cdot 47 \%)\end{array}$ & $\begin{array}{l}204(45.84 \%) \\
988(43.57 \%)\end{array}$ & $\begin{aligned} 36 & (8.09 \%) \\
206 & (9.08 \%)\end{aligned}$ & $\begin{array}{l}12 \\
88\end{array}$ & $\begin{array}{l}(3.7 \%) \\
(3.88 \%)\end{array}$ & $\begin{array}{r}445 \\
2,268\end{array}$ \\
\hline Total & Pathological sera & 422 & 465 & 86 & 43 & & 1,016 \\
\hline
\end{tabular}

TABLE IV

COMPARISON OF INCIDENCE OF BLOOD GROUPS A AND O IN BENIGN PROSTATIC HYPERPLASIA

Reported Series

Place

Blood Groups

O A A:O $\quad \chi^{2}$

Walther et al. (1956)

Prosser (1959)

Bourke and Griffin (1962)

This series

London

Italy

London

Monmouthshire

$\begin{array}{rr}36 & 56 \\ 76 & 9 \\ 117 & 11 \\ 193 & 204\end{array}$

422

465

1.63

$1 \cdot 0$

1.05
1.05

4.99

$92-1.0 \quad 0$

$\begin{array}{lll}1.05 & 0 \\ 13 & 1.05 & 0.13\end{array}$

Total

1.02

Total

Difference from unity (D of F) $=$

Heterogeneity (D of F)

P Heterogeneity 
III). A statistical analysis of the distribution of the ABO groups in all four series is set out in Table IV, which shows that in three series no association was found between blood group A and benign prostatic hyperplasia, but that in the series of Walther et al. there appeared to be a significant excess of group A. However, when all four reports were analysed together no statistically significant association between group $\mathbf{A}$ and benign prostatic hyperplasia was found $\left(\chi^{2}=1.5, P=0.22\right)$, and the four areas were homogenous $\left(\chi^{2}=3 \cdot 85, \mathrm{P}=0.28\right)$.

I should like to thank the physicians, surgeons, and records staff of the Cardiff United Hospitals, Sully
Hospital, Frenchay Hospital, Bristol, St. Woolos Hospital, Newport, the Royal Gwent Hospital, Ebbw Vale Hospital, and Aberbeeg Hospital for their help in collecting this series. I am indebted to Dr. A. C. Kopec of the Nuffield Blood Group Centre for providing controls.

REFERENCES

Aird, I., Lee, D. R., and Roberts, J. A. F. (1960). Brit. med. J., 1, त) 1163.

Beasley, W. H. (1960). Ibid., 1, 1167.

Billington, B. P. (1957). Aust. Ann. Med., 6, 56.

Bourke, J. B., and Griffin, J. P. (1962). Lancet, 2, 1279.

Prosser, I. (1959). Minerva urol., 11, 253.

Walther, W. W., Raeburn, C., and Case, J. (1956). Lancet, 2, 970. Woolf, B. (1955). Ann. hum. Genet., 19, 251. 